\title{
PENGARUH MEDIA PEMBELAJARAN TERHADAP MOTIVASI BELAJAR SISWA KELAS X PROGRAM KEAHLIAN TATA KECANTIKAN RAMBUT DI SMKN 7 PADANG
}

\author{
Indah Utami S.W \\ Program Studi Pendidikan Tata Rias dan Kecantikan, Fakultas Pariwisata dan Perhotelan, Universitas \\ Negeri Padang \\ e-mail: indahutami807@yahoo.com \\ Merita Yanita \\ Program Studi Pendidikan Tata Rias dan Kecantikan, Fakultas Pariwisata dan Perhotelan, Universitas \\ Negeri Padang \\ e-mail: yanitamerita@gmail.com
}

\begin{abstract}
This research is motivated by the learning process. Quantitative research methods with correlational research types.The population is 58 students, technique uses total sampling. Quantitative analysis techniques. The results showed the level of use of instructional media by class $X$ students of hairstyling at Padang State Vocational High School amounted to $75.81 \%$ good category which was viewed from visual media indicators as much as $73.95 \%$ good category and audio visual media by $75.81 \%$ good category. The level of student motivation is $78.74 \%$ in the good category which is viewed from the indicators of desire and desire of success of $79.23 \%$ in the good category, the encouragement and learning needs of $78.16 \%$ in the good category, the hopes and aspirations of the future amount to $78.10 \%$ good category, the award in learning amounted to $77.70 \%$ in the good category, the presence of interesting desires in learning by $50.23 \%$ in the fairly good category and the existence of a conducive learning environment of $82.41 \%$ in the very good category. The results of the analysis and hypothesis testing have a significant effect with a low level of influence of $6.9 \%$.
\end{abstract}

Keywords: Learning Media, Student Learning Motivation

\section{PENDAHULUAN}

Sebagai Negara yang besar pada dasarnya negara kita Indonesia memiliki potensi yang besar untuk menjadi salah satu bangsa yang maju dan lebih baik dari saat ini, dan itu semua dapat kita wujudkan tentunya dengan dukungan sumber daya manusia yang berkualitas, kreatif dan memiliki visi dan misi yang jelas dan terarah untuk kemajuan bangsa. Pendidikan adalah salah satu yang sangat penting bagi kehidupan manusia, karena pendidikan bisa mempengaruhi kualitas hidup. Apalagi saat ini perkembangan teknologi terjadi dengan begitu cepat, sehingga memaksa kita semua harus bisa mengikuti perkembangan zaman jika tidak ingin menjadi orang yang tertinggal. Untuk memenuhi tujuan terciptanya sumber daya manusia yang berkualitas tentunya pendidikan adalah salah satu faktor terpenting yang tidak dapat kita pisahkan dalam kehidupan kita.

Pada dasarnya pendidikan nasional telah mengalami perkembangan yang memerlukan penyesuaian dan pemantapan. Pembaruan sistem pendidikan nasional dilakukan untuk mempengaruhi visi, misi dan strategi pendidikan nasional.

Salah satu upaya pemerintah dalam mencerdaskan bangsa adalah dengan memajukan pendidikan dan mengupayakan berbagai fasilitas yang memadai pada tiap-tiap jenjang lembaga pendidikan.

Pada awalnya teknologi seperti VCD, LCD dan komputer adalah barang mewah yang jarang dimiliki masyarakat, tetapi saat ini telah menjadi barang umum untuk digunakan. Tidak hanya digunakan untuk konsumsi pribadi, hiburan, atau digunakan kantor perusahaan, kini produk teknologi modern juga telah merambah di dunia pendidikan. Pendidikan yang didapatkan dibangku sekolah, tidak semuanya dapat diterima dengan baik oleh siswa, karena tidak semua siswa mempunyai pendapat, pemikiran, dan daya tangkap yang sama terhadap materi pelajaran yang disampaikan oleh guru. Oleh karena itu, guru yang merupakan komunikator dalam proses pembelajaran di dalam kelas harus bisa menguasai kelas. Seorang guru harus bisa menciptakan suatu kondisi atau 
proses yang mampu mengarahkan siswanya untuk melakukan aktivitas belajar, karena dalam hal ini seorang guru mempunyai peran yang sangat penting mengingat tugas seorang guru sebagai motivator.

Dari uraian di atas dapat disimpulkan bahwa pelaksanaan pendidikan itu pada umumnya adalah mengembangkan mutu dan potensi sumber daya manusia untuk membangun bangsa lebih maju dan lebih baik. Adanya perkembangan ilmu pengetahuan dan teknologi juga akan berpengaruh terhadap kualitas sistem pembelajaran di sekolah. Bawasannya dengan kehadiran teknologi yang modern sekolah dituntut untuk lebih kreatif dalam membuat pembelajaran menjadi menarik dan efektif baik dalam proses pembelajaran maupun media pembelajaran sehingga siswa akan menjadi senang dan tidak bosan selama proses pembelajaran berlangsung dan memperoleh hasil belajar yang maksimal.

Media adalah segala bentuk dan saluran yang digunakan untuk menyampaikan informasi atau pesan.Menurut Hamdani (2011:72) mengatakan bahwa “ media apabila dipahami secara garis besar adalah manusia, materi, atau kejadian yang membangun kondisi yang membuat siswa mampu memperoleh pengetahuan, keterampilan, atau sikap". Berdasarkan observasi yang peneliti lakukan siswa tidak mampu memperoleh pengetahuan, kemampuan, dan sikap yang maksimal, karena media sebagai alat yang penting tidak dipenuhi oleh guru mata pelajaran dasar kecantikan rambut, sehingga siswa tidak termotivasi dalam proses pembelajaran.

Media yang menarik akan mempengaruhi motivasi belajar, ketika siswa menilai bahwa apa yang ditampilkan oleh guru itu menarik maka ia akan terdorong atau merasa tertantang untuk mengetahui apa yang akan disampaikan oleh guru sehingga proses belajar akan menjadi lebih menyenangkan. Tetapi sebaiknya jika siswa menilai apa yang ditampilkan guru tidak menarik maka siswa akan datar dalam mengikuti proses belajar.

Pada perkembangan zaman dan dengan perkembangan teknologi, dalam proses pembelajaran siswa untuk lebih aktif maka komputer dapat dijadikan salah satu media untuk membantu dalam proses pembelajaran. Banyak cara yang dapat dikembangkan dalam pembelajaran untuk melibatkan siswa aktif melalui stimulus media.

Menurut Syaiful (2010:43) bahwa media pembelajaran dapat membantu peserta didik dalam proses pembelajaran mata pelajaran dasar kecantikan rambut, media ini memungkinkan siswa lebih aktif dalam mengikuti pembelajan dan selain itu siswa tidak merasa bosan dengan menampilkan bentuk gambar, modul dan lainnya. Dengan menggunakan media pembelajaran berupa gambar, papan tulis, dan suara yang bevariasi, siswa termotivasi dalam mengikuti proses pembelajaran.

Ketika dilakukan wawancara dengan guru mata pelajaran dasar kecantikan rambut di SMKN 7 Padang, guru tersebut belum banyak menggunakan media pembelajaran yang bervariasi.Hal ini menyebabkan guru lebih memilih menggunakan media seadanya di sekolah seperti papan tulis, atau cukup menggunakan buku saja. Akibatnya, selama proses pembelajaran siswa terlihat kurang antusias dan kurang aktif. Tidak banyak siswa ingin bertanya kepada guru dan pada saat mengerjakan tugas kelompok banyak siswa bermain sendiri.Ketika guru melakukan persentasi dari tugas yang diberikan hanya beberapa siswa saja mampu melaporkan hasil dengan jelas dan baik, serta bisa menyimpulkan dengan benar.

Hal ini perlu mendapat perhatian yang lebih oleh setiap guru agar selalu berusaha menciptakan suasana kelas yang konduktif, menarik, dan tidak membosankan untuk siswa sehingga siswa menjadi lebih antusias dan aktif dalam pembelajaran.Salah satu caranya yaitu menggunakan media pembelajaran yang bervariasi. Dengan media yang bervariasi, maka guru dapat memanfaatkannya dalam proses pembelajaran untuk menarik perhatian siswa dan memudahkan dalam menyampaikan materi kepada siswa, salah satu materi yang diajarkan dalam mata pelajaran dasar kecantikan rambut dan salah satu alternatif agar pembelajaran dapat berlangsung secara efisien adalah menggunakan media yang bervariasi.

Dari uraian di atas dapat disimpulkan bahwa media pembelajaran dapat mempengaruhi motivasi belajar siswa, karena pemilihan media yang bervariasi menuntun untuk seorang guru untuk bisa lebih terampil dalam memilih media pembelajaran yang sesuai dengan materi dan metode pembelajaran yang akan digunakan dalam mengajar, agar proses belajar dapat berlangsung dengan menyenangkan dan siswa merasa termotivasi untuk mengikuti pelajaran. Namun kenyataanya, masih terdapat sebagian guru melaksanakan proses pembelajaran tanpa menggunakan media pembelajaran seperti media audio, media visual dan media audio visual. Sehingga pada saat proses pembelajaran berlangsung banyak siswa yang bermain-main, bercerita dengan temannya sehingga mereka kehilangan konsentrasi. Kalau sudah seperti itu, siswa tidak lagi memperhatikan pelajaran yang disampaikan oleh guru dan siswa tidak lagi termotivasi untuk mengikuti pelajaran yang disampaikan gurupun menjadi sia-sia.

Permasalahan yang banyak ditemukan pada siswa tata kecantikan rambut kelas $\mathrm{x}$ yaitu, media pembelajaran yang digunakan kurang bervariasi, siswa tidak antusias dalam belajar, siswa sering mengobrol dengan teman sebangkunya diluar materi pelajaran, sering keluar masuk kelas dengan alasan ingin ke kamar mandi, dan siswa kesulitan memahami materi yang disampaikan.

Menurut Djamarah (2010:120) "kata media berasal dari bahasa latin dan merupakan bentuk jamak dari kata "medium" yang secara harfiah berarti perantara atau pengantar". Dengan demikian, Media adalah segala alat yang digunakan oleh guru dalam proses belajar. Jadi, media dapat memudahkan seorang guru dalam mengajar, selain itu penggunaan media dapat membangkitkan motivasi belajar siswa. Sadiman, dalam Haling (2007:93) mengemukakan bahwa "kata "media" berasal dari bahasa 
latin yang secara harfiah berarti "perantara" atau pengantar".

Gagne dan Briggs dalam Arsyad (2006:4) mengemukakan secara implisit mengatakan bahwa media pembelajaran meliputi alat yang secara fisik digunakan untuk menyampaikan isi materi pengajaran, yang terdidri dari antara lain buku, tape recorder, film, slide, (gambar bingkai), foto, gambar, garafik, televisi, dan komputer. Dengan kata lain, media adalah komponen sumber belajar atau bahan fisik yang mengandung materi intruksional di lingkungan siswa untuk belajar.

Beberapa pendapat ahli di atas maka dapat simpulkan bahwa media adalah salah satu alternatif yang digunakan oleh seorang guru dalam menyampaikan sebuah materi di depan kelas. Dengan menggunakan media seorang guru diharapakan bisa lebih mudah dalam menyampaikan materi dan siswa juga dapat menerima pelajaran dengan baik dan menyenangkan sehingga menimbulkan motivasi siswa untuk belajar.

a. Fungsi Media Pembelajaran

Menurut Sanjaya (2006:169) mengemukakan bahwa secara khusus media pembelajaran memiliki fungsi dan berperan untuk:

1) Menangkap suatu objek atau peristiwa-peristiwa tertentu.

2) Memanipulasi keadaan, peristiwa, atau objek tertentu.

3) Menambah gairah dan motivasi belajar siswa.

b. Jenis- Jenis Media

Menurut Hamdani (2011:248) media dapat di kelompokkan menjadi tiga jenis yaitu:

1) Media Visual.

2) Media Audio.

3) Media audio visual.

c. Prinsip-Prinsip Pemilihan dan Penggunaan Media

1) Tujuan Pemilihan

2) Karakteristik Media

3) Alternatif Pilihan

d. Dasar Pertimbangan Pemilihan dan Penggunaan Media

Menurut Sanjaya dalam Hamdani (2011:257) mengemukakan pertimbangan lain dalam memilih media pembelajaran yang tepat, yaitu menggunakan kata ACTION (Acces, Cost, Tecnology, Interactivity, Organization, Novelty). Untuk lebih jelasnya mengenai hal diatas diuraikan sebagai berikut:

a. Access, artinya kemudahan akses menjadi pertimbangan pertama dalam pemilihan media. Apakah media yang di perlukan itu tersedia, mudah di dapat dan di manfaatkan, akses juga menyangkut aspek kebijakan, apakah media tersebut diizinkan untuk digunakan.

b. Cost, artinya pertimbangan biaya. Biaya yang dikeluarkan untuk penggunaan suatu media harus seimbang dengan manfaatnya. c. Technology, artinya ketersediaan teknologinya dan kemudahan dalam penggunaanya.

d. Interctivity, artinya mampu menghadirkan komunikasi dua arah atau interaktivitas.

e. Organization, artinya dukungan organisasi atau lembaga dan cara pengorganisasiannya.

f. Novelty, artinya aspek kebaruan dari media yang dipilih. Media yang lebih baru biasanya lebih menarik dan lebih baik.

Menurut Haling (2007:104) sebagai pedoman pemilihan media pembelajaran, antara lain dapat dipertimbangkan hal-hal sebagai berikut:

a. Sebelum memilih media pembelajaran, pembelajar harus menyadari bahwa tidak ada satu pun yang paling baik untuk semua tujuan. Tiap media tertentu mempunyai kebaikan dan kelemahan, serta keserasian tertentu guna mencapai tujuan pembelajaran yang telah dirumuskan.

b. Pemilihan media hendaknya dilakukan secara objektif, artinya benarbenar digunakan dengan dasar pertimbangan efektifivitas pembelajaran, bukan karena kesenangan pembelajar atau sekedar selingan.

c. Pemilihan media hendaknya memperhatikan syaratsyarat sebagai berikut:

1) Sesuai dengan tujuan pembelajaran yang akan di capai.

2) Sesuai dengan pebelajar yang belajar.

3) Ketersediaan bahan media.

4) Biaya pengadaan.

5) Kualitas/mutu teknik.

Berdasarkan uraian di atas, maka dapat disimpulkan bahwa pemilihan dan penggunaan media pembelajaran harus penuh dengan pertimbangan, karena tidak semua media pembelajaran dapat diterima oleh siswa, jadi pemilihan dan penggunaan media hendaklah di pertimbangkan sesuai dengan materi dan tujuan pemeblajaran yang akan di capai.

Selanjutnya Sardiman (2016:73) mengatakan bahwa "istilah motivasi berasal dari kata motif yang dapat diartikan sebagai daya upaya untuk mendorong seseorang untuk melakukan sesuatu.

Hamalik (2001:158) mengemukakan bahwa "motivasi adalah perubahan energi dalam diri (pribadi) seseorang yang di tandai dengan timbulnya perasaan dan reaksi untuk mencapai tujuan". Menurut Uno (2015:1) mengemukakan bahwa "motivasi adalah dorongan dasar yang yang menggerakkan seseorang untuk bertingkah laku".

Thomas M. Risk dalam Rohani(2010:12) memberikan pengertian motivasi sebagai berikut:

We may Definen motivation, in a pedagogical sense, as the concious effort on the part of the 
teacher to establish in students motives leading to sustained activity toward the learning goals (motivasi adalah usaha yangdi sadari oleh pihak guru untuk menimbulkan motif-motif pada diri pesertadidik/pelajar yang menunjang kegiatan ke arah tujuan belajar).

Beberapa pengertian di atas, mengenai motivasi maka dapat di simpulkan bahwa motivasi adalah dorongan yang berasal dari dalam diri individu, yang menggerakkannya untuk melakukan perubahan tingkah laku untuk mencapai suatu tujuan.

a. Jenis- Jenis Motivasi Belajar

Sahabuddin (2007:140) mengemukakan bahwa ada dua jenis motivasi, yaitu:

1) Motivasi intrinsik

2) Motivasi ekstrinsik

b. Prinsip- Prinsip Motivasi Belajar

Motivasi sebagai dasar penggerak yang mendorong aktivitas belajar. Motvasi intrinsik lebih utama daripada motivasi ekstrinsik dalam belajar. Motivasi berupa pujian lebih baik daripada motivasi berupa hukuman. Motivasi berhubungan erat dengan kebutuhan dalam belajar. Motivasi dapat memupuk optimisme dalam belajar. Motivasi melahirkan prestasi belajar.

c. Fungsi Motivasi dalam Belajar

Memberi semangat dan mengaktifkan peserta didik supaya tetap berminat dan siaga. Memusatkan perhatian peserta didik pada tugas-tugas tertentu yang berhubungan dengan pencapaian belajar. Membantu memenuhi kebutuhan akan hasil jangka pendek dan jangka panjang.

d. Cara Membangkitkan Motivasi Belajar Siswa.

Memberi angka, hadiah, kompetisi, egoinvolvement, memberi ulangan, mengetahui hasil, pujian, dan hukuman.

e. Indikator Motivasi Belajar

Menurut Uno (2015:23) indikator motivasi belajar adalah sebagai berikut:

1. Adanya hasrat dan kenginan berhasil.

2. Adanya dorongan dan kebutuhan dalam belajar.

3. Adanya harapan dan cita-cita masa depan.

4. Adanya penghargaan dalam belajar.

5. Adanya keinginan yang menarik dalam belajar.

6. Adanya lingkungan belajar yang kondutif

Menurut Djamarah (2008:169) indikator motivasi belajar adalah sebagai berikut:

1. Menggairahkan anak didik

2. Memberi harapan realitis

3. Memberi insentif

4. Menggairahkan perilaku anak didik

Dari uraian indikator motivasi belajar di atas maka dapat disimpulkan bahwa motivasi belajar dapat timbul karena faktor instrinsik yang berupa hasrat dan keinginan berhasil, dorongan kebutuhan belajar serta harapan akan cita-cita. Sedangkan faktor ekstinsiknya adalah adanya penghargaan, kegiatan belajar yang menarik lingkungan belajar yang kondusif. Kedua faktor tersebut disebabkan oleh rangsangan tertentu sehingga seseorang berkeinginan untuk melakukan aktivitas belajar yang lebih giat dan semangat.Rangsangan tersebut adalah hakikat motivasi belajar yang terdapat pada siswa yang sedang belajar untuk mengadakan perubahan tingkah laku. Indikator yang dijadikan dalam penelitian adalah menurut Uno (2015:23) yaitu:

1. Adanya hasrat dan kenginan berhasil.

2. Adanya dorongan dan kebutuhan dalam belajar.

3. Adanya harapan dan cita-cita masa depan.

4. Adanya penghargaan dalam belajar.

5. Adanya keinginan yang menarik dalam belajar.

6. Adanya lingkungan belajar yang kondutif

\section{METODE}

Penelitian ini menggunakan pendekatan kuantitatif dengan jenis penelitian korelasional. Penelitian ini dilaksanakan pada bulan Oktober 2018 di SMK Negeri 7 Padang.

Pada penelitian ini, populasi yang dimaksudkan adalah siswa jurusan Tata Kecantikan kelas X di SMK N 7 Padang. Sampel yang digunakan sebanyak 58 orang sesuai dengan banyak populasi Pengambilan sampel dengan menggunakan rumus total sampling.

Jenis teknik analisis data yang dikunakan terdiri dari teknik analisis statistik deskriptif dan teknik analisis inferensial. Dengan teknik pengumpulan data menggunakan observasi, kuosioner atau angket dan dokumentasi. Instrumen yangdigunakan yaitu rubrik penilaian dengan skala likert. Selanjutnya melakukan uji instrumen yang terdiri dari uji dari uji validitas dan uji reabilitas.

\section{HASIL DAN PEMBAHASAN}

\section{A. Hasil}

Setelah diperoleh hasil perhitungan analisis deskriptif tiap indikator, untuk indikator pengetahua dapat dilihat pada Tabel 1.

Tabel 1. Rangkuman Hasil Analisis Data Per Indikator Media Pembelajaran.

\begin{tabular}{|c|c|c|c|c|c|}
\hline No & Inidator & $\mathbf{n}$ & $\mathbf{N}$ & $\mathbf{\%}$ & Kategori \\
\hline 1 & $\begin{array}{c}\text { Media } \\
\text { visual }\end{array}$ & 4289 & 5800 & $73,95 \%$ & Baik \\
\hline 2 & $\begin{array}{c}\text { Media } \\
\text { audio } \\
\text { visual }\end{array}$ & 2306 & 2900 & $79,52 \%$ & Baik \\
\hline \multicolumn{2}{|c|}{ Jumlah } & 6595 & 8700 & $75,81 \%$ & Baik \\
\hline
\end{tabular}


Kedua indikator media pembelajaran di uraikan sebagai berikut:

a) Media Visual

Media visual berada pada kategori baik dengan tingkat persentase $73,95 \%$.

b) Media Audio Visual

Media audio visual berada pada kategori baik atau $79,52 \%$.

Berdasarkan hasil analisis pada Tabel 49, variabel media pembelajaran $(\mathrm{X})$ di peroleh hasil media visual tergolong pada kategori baik dan media audio visual tergolong pada kategori baik. Jadi dapat disimpulkan bahwa penggunaan media pembelajaran tergolong pada kategori baik dengan tingkat persentase $75,81 \%$

Tabel 2. Rangkuman Hasil Analisis Data Per Indikator Motivasi Belajar

\begin{tabular}{|c|c|c|c|c|c|}
\hline No & Indikator & $\mathrm{N}$ & $\mathrm{N}$ & $\%$ & Kategori \\
\hline 1 & $\begin{array}{l}\text { Hasrat dan } \\
\text { keinginan } \\
\text { berhasil. }\end{array}$ & 919 & 1160 & $79,23 \%$ & Baik \\
\hline 2 & $\begin{array}{l}\text { Dorongan } \\
\text { dan } \\
\text { kebutuhan } \\
\text { dalam } \\
\text { belajar }\end{array}$ & 680 & 870 & $78,16 \%$ & Baik \\
\hline 3 & $\begin{array}{l}\text { Harapan dan } \\
\text { cita-cita } \\
\text { masa depan }\end{array}$ & 453 & 580 & $78,10 \%$ & Baik \\
\hline 4 & $\begin{array}{l}\text { Penghargaan } \\
\text { dalam } \\
\text { belajar }\end{array}$ & 676 & 870 & $77,70 \%$ & $\begin{array}{l}\text { Cukup } \\
\text { baik }\end{array}$ \\
\hline 5 & $\begin{array}{l}\text { Keinginan } \\
\text { yang } \\
\text { menarik } \\
\text { dalam } \\
\text { belajar }\end{array}$ & 219 & 436 & $50,23 \%$ & Baik \\
\hline 6 & $\begin{array}{l}\text { Lingkungan } \\
\text { belajar yang } \\
\text { kondutif }\end{array}$ & 478 & 580 & $82,41 \%$ & $\begin{array}{l}\text { Sangat } \\
\text { baik }\end{array}$ \\
\hline & Jumlah & 3425 & 4350 & $\begin{array}{c}78,74 \\
\%\end{array}$ & Tinggi \\
\hline
\end{tabular}

Dari Keenam indikator motivasi belajar di atas maka dapat diuraikan sebagai berikut:

a) Hasrat dan kenginan berhasil.

indikator motivasi belajar yang berada pada kategori baik dengan tingkat persentase 79,23\%.

b) Dorongan dan kebutuhan dalam belajar. indikator motivasi belajar yang berada pada kategori baik dengan tingkat persentase $78,16 \%$.

c) Harapan dan cita-cita masa depan. indikator motivasi belajar yang berada pada kategori baik dengan tingkat persentase $78,10 \%$.

d) Penghargaan dalam belajar. indikator motivasi belajar yang berada pada kategori baik dengan tingkat persentase $77,70 \%$.

e) Keinginan yang menarik dalam belajar. indikator motivasi belajar yang berada pada kategori cukup baik dengan tingkat persentase $50,23 \%$.

f) Lingkungan belajar yang kondutif.

indikator motivasi belajar yang berada pada kategori sangat baik dengan tingkat persentase $82,41 \%$.

Jadi, dapat disimpulkan motivasi belajar siswa SMK Negeri 7 Padang berada pada kategori baik dengan tingkat persentase sebesar 78,74\%.

Setelah diperoleh hasil perhitungan analisis statistik inferensial, maka dilakukan uji normalitas data, analisis linear sederhana dan uji korelasi product moment dengan Sig $5 \%$

Tabel 3. Hasil Uji Normalitas Data Penelitian

\begin{tabular}{|c|c|c|c|c|}
\hline Variabel & $\mathbf{X}_{\text {hitung }}^{2}$ & $\mathbf{X}_{\text {tabel }}^{2}$ & Df & Ket. \\
\hline $\begin{array}{l}\text { X }: \text { Media } \\
\text { Pembelajar } \\
\text { an }\end{array}$ & 14,690 & 47,400 & 33 & Normal \\
\hline \multicolumn{5}{|l|}{$\begin{array}{l}\text { Y : Motivasi } \\
\text { Belajar }\end{array}$} \\
\hline & 22,586 & 28,869 & 18 & Normal \\
\hline
\end{tabular}

Sumber: Hasil Olah Data melalui SPSS 20

Tabel 4. Analisis Linear Sederhana

\begin{tabular}{lccccc}
\hline Variabel & $\mathbf{B}$ & $\mathbf{F}_{\text {hitung }}$ & Sig & $\mathbf{T}_{\text {hitung }}$ & Sig \\
\hline Konstanta & 51,258 & & 13,175 & 0,000
\end{tabular}

\begin{tabular}{|c|c|c|c|c|c|}
\hline & & 4,127 & 0,047 & & \\
\hline $\begin{array}{l}\text { Media } \\
\text { embelajar }\end{array}$ & 0,069 & & & 2,032 & 0,047 \\
\hline
\end{tabular}

Berdasarkan tabel 4 diatas, diperoleh persamaan regresi $\alpha=51,258$ dan $b=0,069$ sehingga persamaan regresi linear yang dihasilkan adalah:

$$
Y=51,258+0,069 X
$$

Untuk mengetahui linear regresi sederhana digunakan uji $\mathrm{F}$ melalui tabel anova. Hipotesis yang diterima adalah $\mathrm{H} 0: \alpha: \beta$ atau $\beta \neq 0$. Dari hasil perhitungan uji $\mathrm{F}$ diperoleh Fhitung sebesar 4,127 dengan Ftabel $(0.05: 1: 58)$ sebesar 4,01 yang berarti $F$ hitung lebih besar dari F tabel. Dengan demikian, di karenakan, Fhitung lebih besar dari Ftabel maka H0 ditolak dan H1 
diterima yang berarti ada sifat ketergantungan dari variabel media pembelajaran terhadap motivasi belajar siswa sehingga secara langsung hasil pengelolaan data dalam penelitian ini dengan hipotesis yang mengatakan "diduga ada pengaruh media pembelajaran terhadap motivasi belajar siswa kelas $\mathrm{X}$ program keahlian tata kecantikan rambut di SMK Negeri 7 Padang" dapat diterima.

Tabel 5. Hasil Uji Korelasi Product Moment dengan Sig $5 \%$

\begin{tabular}{ccccc} 
Model & R & $\begin{array}{c}\text { R } \\
\text { Square }\end{array}$ & $\begin{array}{c}\text { Adjusted R } \\
\text { Square }\end{array}$ & $\begin{array}{c}\text { Std Error of } \\
\text { the Estimet }\end{array}$ \\
\hline 1 & $0,262^{\mathrm{a}}$ & 0,069 & 0,052 & 4,91895
\end{tabular}

Sumber: Hasil Olah Data melalui SPSS 20

Berdasarkan analisis korelasi hasil perhitungan product moment diperoleh hasil korelasi antara media pembelajaran (X) dan motivasi belajar (Y) yaitu (r) sebesar 0,262 setelah di konsultasikan pada tabel 3, interprestasi niali $\mathrm{r}$ pada BAB III yang di kemukakan oleh Sugiyono skor tersebut berada 0,20 - 0,399 yang memiliki tingkat pengaruh rendah. Koefisien determinasinya yaitu $r^{2}=0,069$ atau $6,9 \%$ berarti adanya pengaruh media pembelajaran terhadap motivasi belajar siswa tata kecantikan rambut kelas $\mathrm{X}$ sebesar 6,9\%

\section{B. Pembahasan}

Hasil penelitian ini menunjukkan bahwa media pembelajaran mempengaruhi motivasi belajar siswa kelas X program keahlian tata kecantikan rambut di SMK Negeri 7 Padang, korelasi atau hubungan antara media pembelajaran dan motivasi belajar siswa di peroleh pengaruh yang berada pada kategori rendah. Hal ini berarti terdapat hubungan korelasional yang positif antara media pembelajaran dengan motivasi belajar. Media pembelajaran yang digunakan oleh guru beragam diantaranya media visual (seperti gambar, buku paket, modul dan power point), media audio visual (seperti video) yang dapat mempengaruhi dan meningkatkan motivasi belajar siswa dalam memahami dan menerima materi pelajaran yang di sampaikan oleh guru. Berdasarkan hasil penelitian di atas, maka dapat disimpulkan bahwa media pembelajaran di SMK Negeri 7 Padang sudah kuat, hal ini dapat dilihat dari penggunaan media visual dan media audio visual yang digunakan oleh guru dalam menyampaikan materi dalam proses pembelajaran. Hal ini berarti di SMK Negeri 7 Padang sudah mengupayakan dan mengembangkan media pembelajaran demi meningkatkan kualitas pendidikan yang lebih baik bagi siswa.
Sedangkan motivasi belajar siswa kelas X program keahlian tata kecantikan rambut di SMK Negeri 7 Padang sudah tinggi, hal ini dapat dilihat dengan adanya keinginan siswa untuk selalu berusaha berhasil dalam proses pembelajaran sehingga siswa dapat meraih prestasi yang baik. Penggunaan media juga memberikan kontribusi dalam meningkatkan motivasi belajar siswa yang tergolong dalam kategori tinggi di tinjau dari aspek diantaranya : adanya hasrat dan keinginan berhasil, adanya dorongan dan kebutuhan dalam belajar, adanya harapan dan cita-cita masa depan, adanya penghargaan dalam belajar, adanya keinginan yang menarik dalam belajar, adanya lingkungan belajar yang kondutif. Dimana hal ini dapat diketahui dari pemberian meteri pembelajaran untuk mencapai tujuan pembelajaran yang telah ditetapkan, didukung dengan media pembelajaran yang memadai yang dapat memotivasi siswa untuk berhasil dalam proses pembelajaran.

Berdasarkan hasil pengujian hipotesis, bahwa terdapat pengaruh variabel media pembelajaran terhadap varaibel motivasi belajar siswa kelas $\mathrm{X}$ program keahlian tata kecantikan rambut di SMK Negeri 7 Padang. Hasil penelitian menunjukkan bahwa media pembelajaran merupakan salah satu dari beberapa faktor yang dapat mempengaruhi motivasi belajar siswa.Inti dari penelitian ini adalah penggunaan media pembelajaran dapat meningkatkan motivasi belajar siswa apabila dilaksanakan dengan baik, sehingga penelitian ini dapat di kembangkan untuk mengetahui penggunaan media pembelajaran di sekolah.

\section{Ucapan Terima Kasih}

Terimakasih kepada kedua orang tua yang selalu mendoakan dan memberi dukungan kepada penulis baik berupa moril maupun materil.

Terimakasih kepada pihak SMK Negeri 7 Padang yag telah mengizinkan tempatnya untuk dilakukan penelitian.

\section{PENUTUP}

\section{Simpulan}

Berdasarkan hasil penelitian dan pembahasan hasil penelitian mengenai pengaruh media pembelajaran terhadap motivasi belajar siswa kelas X program keahlian tata kecantikan rambut di SMK Negeri 7 Padang, dapat di simpulkan yaitu, Penggunaan media pembelajaran di SMK Negeri 7 Padang sebesar 75,81\% yang tergolong pada kategori baik. Hal ini dapat dilihat dari penggunaan media visual sebesar $73,95 \%$ kategori baik dan media audio visual sebesar $75,81 \%$ kategori baik. Motivasi belajar siswa SMK Negeri 7 Padang tergolong pada kategori baik sebesar $78,74 \%$. Hal ini dapat dilihat dari 
aspek adanya hasrat dan keinginan berhasil sebesar $79,23 \%$ kategori baik, adanya dorongan dan kebutuhan dalam belajar sebesar 78,16\% kategori baik, adanya harapan dan cita - cita masa depan sebesar 78,10\% kategori baik, adanya penghargaan dalam belajar sebesar $77,70 \%$ kategori baik, adanya keinginan yang menarik dalam belajar sebesar $50,23 \%$ cukup baik, serta adanya lingkungan belajar yang kondusif sebesar 82,41\% kategori sangat baik. Adanya pengaruh yang signifikan pada media pembelajaran terhadap motivasi belajar siswa kelas X program keahlian tata kecantikan rambut di SMK Negeri 7 Padang dan tingkat pengaruhnya tergolong rendah sebesar $6,9 \%$.

\section{Saran}

1. Bagi kepala SMK Negeri 7 Padang sebagai pimpinan tertinggi dan sebagai panutan bagi bawahannya untuk lebih meningkatkan sarana dan prasarana di sekolah terutama dalam hal penyediaan media pembelajaran yang memadai.

2. Bagi guru SMK Negeri 7 Padang, untuk lebih mengembangkan penggunaan media pembelajaran dalam setiap kegiatan belajar mengajar, sehingga siswa lebih termotivasi untuk mengikuti pelajaran.

3. Penggunaan media pembelajaran berpengaruh secara signifikan terhadap motivasi belajar siswa. Oleh karen itu, disarankan kepada kepala sekolah dan guru agar lebih meningkatkan kualitas penggunaan media pembelajaran, sehingga siswa dapat termotivasi dalam mengikuti pelajaran sehingga tujuan pembelajaran yang diinginkan dapat tercapai dengan baik.

\section{DAFTAR PUSTAKA}

Ahmad, Rohani. 2010. Pengelolaan Pengajaran. Jakarta: PT Rineka Cipta

Ali, Muhammad. 2000. Penelitian Kependidikan Prosedur \& Startegi.Bandung.

Amalia, Indahyani. 2014. Pengaruh Pemanfaatan Teknologi Informasi terhadap

Motivasi Belajar Siswa MAN LAMPA Kabupaten Polewali Mandar.

Ali, Muhammad. 2000. Penelitian Kependidikan Prosedur \& Startegi.Bandung.

Amalia, Indahyani. 2014. Pengaruh Pemanfaatan Teknologi Informasi terhadap

Motivasi Belajar Siswa MAN LAMPA Kabupaten Polewali Mandar.

Arikunto, Suharsimi. 2013. "Prosedur Penelitian Suatu Pendekatan Praktek".Jakarta: PT. Rineka Cipta.

Azhar, Arsyad. 2010. Media Pembelajaran. Jakarta: Raja Grafindo Persada.
Arsyad, Azhar. 2014. Media Pembelajaran. Cet. 17.Jakarta PT. Raja Grafindo.

Djamarah, Syaiuful, Bahri. 2010. Strategi Belajar Mengajar. Cet 14. Jakarta: Rineka Cipta.

Haling, Abdul, dkk. 2007. Perencanaan Pembelajaran. Cet.1. Makassar: Badan Penerbit UNM.

Hamalik, Oemar. 2001. Proses Belajar Mengajar. Jakarta: PT Bumi Aksara.

Hamdani 2011.Strategi Belajar Mengajar.Bandung : CV Pustaka Setia. 